\title{
Martin Eden's Pursuing Process and Spirit
}

\author{
Rong Hou \\ The School of Foreign Languages, Shan'xi Normal University, Linfen, China
}

\begin{abstract}
Martin Eden is a novel with a property of autobiography written by American realistic writer Jack London. Its main characteristic is the exposure of American society's hypocrisy and decay. The essay mainly discusses the struggling process of Martin Eden, and is divided into three parts: love, knowledge and the world, and the hero himself to display the hero's pursuing spirit and his self-improvement. The latter part describes the hero's disintegration in "mind" and the success on the "surface" at the same time, reveals the contradiction between the main part of the society's hypocrisy and the hero's pure pursuing mind, thus deepens the precious quality of the hero's active pursuing spirit in the complex, uncertain society.
\end{abstract}

Index Terms-Martin Eden, pursuit, love, self—improvement, disintegration

\section{INTRODUCTION}

Written by Jack London in 1909, Martin Eden, with a property of autobiography, is seen as a famous novel which represents the author's achievements in art and his writing style. Martin was a young sailor about twenty-one years old; by chance he went to the hall of a high class family, knowing Ruth for the first time. The entire atmosphere in the room and the beauty of her made him excited and thrilled. And in order to match himself with Ruth and win her, he started the process of pursuing: love, beauty, knowledge and the world, and set himself as a writer. Indeed Ruth was attracted by Martin's enthusiasm and strength and fell in love with him. But the process of Martin's success was so long that before his success, during a time of hardness, all people around him including Ruth, did not understand him. Even worse, Ruth left him due to her family's class discrimination and the pressure of her environment. However, after his success, all things were changed. People of the upper class began to respect him and invited him to dinner. And Ruth came back to show her love. So Martin was puzzled. When he realized the reason of people's changed attitude were his fame and money, he felt disappointed and even despaired. At last he committed suicide in the sea.

On a whole the novel criticized the upper class's hypocritical quality through Martin's success and suicide. But a large part of the novel described the process of Martin's pursuit. His strong desire was love at first, accompanied by more understanding of beauty and the world. Despite of his last tragic end, in the process of pursuing, Martin was like a lovely cobble with strong power, conceiving a big dream and struggle for it. Even though the cobble disappeared before it has changed to jade, it displayed beautiful color, for it did try and struggle for its dream.

\section{The PROCESS OF PURSUING}

Life can always be seen as a process of pursuing. For Martin Eden, this process started from the moment he saw Ruth to the moment of his success. Though his first twenty years can also be seen a process of pursuing, for example, pursuing a short-time work on the sea, or pursuing a happy time in the drinking place. But it's not the pursuit in the real meaning. What happened was just because of his nature, not from his heart. Inspired by Ruth's beauty, he gradually awakened himself to another world, a world in which he knew what he wanted, "he knew at last, clearly and definitely, that it was beauty, and intellect, and love that he must have.’[1]

\section{A. The Pursuit of Love}

Love plays an important part in Martin's life. It was out of love for the beautiful girl that he started the process of struggle, and the beauty property in his mind sustained him to insist on his dream. It can be said that all he did was just because of love, because of his desire to win the beauty in his heart. And in the process of pursuing, his love matured as well as his view on love. He enjoyed the beauty of love.

\section{The Beginning and the development of Love}

For Martin Eden, the abstract word "love" became concrete in the existence of a beautiful girl Ruth. He himself was sensitive toward beauty and love. For "he had starved for love all his life. His nature craved love."[1].At the first sight of Ruth, he likened her to a pale gold flower upon a slender stem, and looked at her as a spirit, a goddess. He thought of her laughter as tinkling silver bells, the girl was so different for him, because in her eyes he saw immortal soul, and at the thought of her, he wanted to be better to catch her, win her, and conquer her. He sticked to love resolutely. "The best that was in him was pouring out in splendid flood. The very thought of her ennobled and purified him, made him better" [1] Ruth's cleanness and purity reacted on him, so that he underwent a moral resolution. He got rid of the bad habits and began to wash his teeth and scrub his hands, even drank no more. "He dared not go near Ruth's neighborhood in the daytime, but night found him lurking like a thief around the Morse home."[1] Peeping secretly at the windows and looking at the very walls that sheltered her made him feel that his blood turned to wine and sang through his veins. 
Martin's mind on love is pure and firm. He settled on the idea of "God's own mad lover dying on a kiss", and did all things for the win of love. Facing the problem of love, the beautiful girl, he was worried and self-abased. So he did not know what was the proper time for him to visit her for the second time. So only standing under the tree near her house to look at her window was so much a happy thing for him. And the night he rejected Lizzie Connolly and looked up at Ruth's window and murmured "that date was with you, Ruth, I kept it for you [1] showing the innocent heart of a young lover.

With much more time of meeting Ruth, and with a process of his self-improvement, Martin's view on love developed into a clear mind. Although he went to the field of knowledge, and was attracted by it, he always knew that he was a lover first and would always so. All other things he pursued were subordinated to love. The love for Ruth was the reason for his pursuit, and was also the reason for him to sustain his pursuit. In the discussion with Olney, he realized the shortcoming of Ruth's logic mind. But he thought it did not matter, and he formed a new love concept, which was "Reason had nothing to do with love. It mattered not whether the woman he loved reasoned correctly or incorrectly. Love was above reason."[1] His view of love was in a hasty speed of development.

\section{The maturity of love}

Attracted by Martin's outside strength and inside power, Ruth fell in love with Martin. Unfortunately, this kind of "maturity of love" was not referring to their happy ending, but Martin's attitude toward love.

Before Martin and Ruth's part, Martin's love toward Ruth was the fresh air of a young first-lover's heart. There was not so much reason in it. But when Ruth came back to show her love after Martin's success, he realized that the part of illusion in his past love was more than the part of reality. His love toward Ruth was much more of the image in his mind than Ruth herself; he did not understand Ruth fully. At this time he knew that the reason of Ruth's coming back were his fame and money, and it contradicted with his love principle that "All things may go astray in this world, but not love." He realized that his feeling then toward Ruth was not love at that moment, and he saw clearly the hypocrisy of the upper class, to which Ruth belonged, so he rejected her.

Martin's mature view on love can also be shown at his attitude toward Lizzie, a girl who loved him deeply all the time. When they met again Lizzie expressed her love heart, but Martin did not accept it, for he knew that he was different from the man he was, and he could not accept a lover easily as past. And he must be responsible for it. Also he could not bring his past time back, nor could he go back to the class he had belonged to, but Lizzie just belonged to it. So in this condition Martin analyzed their positions in a clear love mind. He rejected Lizzie, just because he was still faithful to love, from soul, and it could not be the one with a simple love heart and a little blind mind.

\section{B. The Pursuit of Knowledge and the World}

For the hero Martin Eden, love was the first and the most important reason of his pursuit. But all the things he did under this reason displayed his pursuit of knowledge and the world. This pursuit is the addition of the pursuit of love, but the role of his pursuing knowledge was so important that it influenced his view on love, even his view on the concept of value.

\section{A field which frightened the hero}

Martin had little education, and things that he knew came from his experience. So when it comes to books, grammar, and knowledge, he seemed so ignorant and self-abased. At first, the field of knowledge frightened him, but also stimulated him at the same time. He did not know what trigonometry was, even math, he did not know what the meaning of English major was, and in the library, he was appalled at the vast edifice of etiquette, thinking that it would take all of a man's time to be polite. In addition, due to his lack of basic knowledge, it was not easy for him to read even simple works, let alone works on philosophy, physics, ecomomics, and so on. So what he could do was reading the dictionary to resolve the new words for him, and look up the phrases he had never seen. This process was hard for him.

\section{A field can be conquered}

Martin Eden grew from a young sailor to a famous writer who knew more about the world and a clear form of life philosophy. An important reason was that he was a man loving knowledge himself. If Ruth was the person who led him get into the gate of knowledge, the whole process of his pursuit in that field ascribed a lot to himself. He told Ruth that he took study kindly, like a duck to water. And for the pursuit of knowledge, he did a lot which was not easy for others. In the writing field, which he loved, he wrote prolifically and intensely, from morning till night, and he was occupied by a desire of creation. Besides, his reading dealt with different fields, from physics to chemistry, from algebra to economics. With so much time he devoted to study, and with so many fields he devoted to read, his curiosity toward the world increased. When reading Spencer's works, he conceived a mood of wondering. It attracted him a lot. And after reading it, he comprehended the organization of the world, the play and interplay of force and matter. This kind of understanding excited him. In the process of pursuing knowledge, he had been mastered by curiosity all his days. He wanted to know. In the novel, the author thus described Martin's ability: "he did not dream that such persons who were given to probing the depths and to thinking ultimate thoughts were as lonely eagles sailing solitary in the azure sky far above the earth and its swarming freight of gregarious life."[1]

And indeed Martin found something in the field of knowledge. Facts proved this point. In chapter XIII, in the conversation between Martin, Ruth and Olney, who was Ruth's classmate and also belonged to the upper class, pointed out Martin's ability. He pointed clearly to Ruth that Martin knew what's best for himself, and Martin knew more about the world, and life, and man's place, and all the rest, than Arthur, or Norman, or Ruth, or himself. This was the first time 
of challenging Ruth's "teacher position" toward Martin, because Martin surpassed her in the field of knowledge, although Martin and Ruth both didn't realize it.

There were two other examples of Martin's achievement in the ocean of knowledge. At Ruth's family party, in the conversation with professor Caldwell, who taught at California University, Martin contaminated the professor with his own earnestness, challenging him to speak his mind. And indeed he achieved his goal. Then the conversation went on, while Martin found out the shortcoming of the knowledge of that college professor, that was, he lacked the knowledge of biology. And professor Caldwell was surprised to acknowledge that what Martin said was right. It showed that the knowledge Martin mastered had provided him the ability to stand in a clear position to look at the world around him, including the college, which was like a paradise for him in the past. Another example was Martin's acquaintance with Brisssenden, who was a socialist, owning a deep background of knowledge and talent, saw clearly the upper class's hypocrisy and emptiness. Such a person appreciated Martin's writing talent and his concept of value, and took him to a crowd of people who conceived their own view on different fields of philosophy one night. That night was a glimpse of fairyland according to Martin. At last after Martin's success, when he met one person of that crowd again, he said: "That night was the only one night for me, I was in paradise."

From things above, it can be seen that in the process of pursuit, Martin walked on the road of knowledge, and gradually enriched himself. No matter what was the end of him, his pursuit proved that the field of knowledge could be conquered by him.

\section{The Pursuit of Himself}

The knowledge Martin gained was the accessory of his pursuit of love, so was his pursuit of himself. He did not pursue the real one of himself on purpose. It's just from the whole process of pursuing that he knew himself better, and always improved himself from all possible ways.

\section{The fighting spirit}

Besides the role of love that played on Martin Eden's success, an important factor was his fighting spirit. In the process of pursuing himself, he always showed it. Whether it was in the fight of his childhood, or in the hard time of writing, he never gave up, and his fighting spirit grew as well as himself.

The novel describes an unforgettable fighting that lasts more than ten years between Martin and a boy. "It reminded him of his first fight, when he was six years old, when he punched away with the tears running down his cheeks while other boys, two years his elder, had beaten and pounded him into exhaustion. He saw the ring of boys howling like barbarians as he went down at last, writhing in the throes of nausea, the blood streaming from his nose and the tears from his bruised eyes ... But he felt strengthened by the memory of that. He had always stayed and taken his medicine. Cheese-Face had been a little friend at fighting, and had never once shown mercy to him. But he had stayed! He had stayed with it[1]" When Martin was eleven, they had a fight which was indeterminate. But he never had such a mind of stopping fight to allow Cheese-Face to whip him. The last fight was when Martin was seventeen years old. Though Martin was beaten black and blue, he continued fighting. It was impossible for him to quit. Finally, Martin won the fight. From this fighting, we can see that Martin was a brave and indomitable fighter when he was young.

While studying magazines, Martin took notice of the stories, articles and poems that editors see fit to publish. He drew up lists of effective and fetching mannerisms that included the tricks of narration, exposition, style, point of view, contrast and epigrams. He sought thoughts and collected lists of strong phrases, the phrases of living language, phrases that hit acid and scorched. "His was deliberate, creative genius, and, before he began a story or poem, the thing itself was already alive in his brain, with the end in his conscious possession."[1] He found that the writing was the culminating act of a long mental process that drew together scattered threads of thought and finally generalized upon all the data with which his mind was burdened. Writing is full of hardship. You can not make achievements until you have experienced difficulties and conquered them. Martin made full use of time to write and study by cutting his sleep to five hours, writing creatively, intensively and industriously from morning till night. He was so amazed at writing that he had to give up his working as a sailor. Life was real and cruel. He ran out of money, and publisher's checks were far away as ever. At this time, he was living on credit. The owners of the fruit shop stopped his credit, even his landlord urged him to move away. Martin encountered the difficulty that at any time he would be forced to leave home and wander about. He had to pawn all his valuable things to pay for his rent and food. The rejection slips accumulated and the money dwindled until Martin had nothing but potatoes to eat, three times a day. Even if he was at the elbows, he firmly sticked to his great ideal of becoming a writer, refusing to get a fixed job to work at Ruth's father's law office. London depicts how difficult it is for a young writer to find success in writing. The people around Martin were indifferent, cold and hostile to him when he concentrated on writing instead of finding a job and fought against starvation. Even under such serious environment, Martin sticked to his writing.

\section{The improvement of appearances}

Martin was a sailor at the beginning, and all the atmosphere and culture of the working class people influenced him, and reflected on him. For example, he felt uncomfortable of wearing the suit's collar for the first time. And before meeting Ruth, he had never washed his teeth. Ruth's cleanness and purity made him feel in himself a desire to be clean. So he washed his teeth, and began to use nail-brush and toilet-tool, and so on. All this may be tiny for anyone who belonged to the upper class, but it was unusual for Martin Eden, a person who was used to a sailor's life. This kind of action showed that Martin wanted himself to be better. Even though it was in the appearances, it reflected Martin's 
process of pursuing himself from a profiling point.

\section{The improvement of the inner mind}

The appearance of Ruth awakened Martin's mind of beauty to a certain extent, more properly speaking awakened Martin himself. From the process of pursuing, Martin grew gradually from a kind of a bleak mind to a mature and clear mind. He slowly found what he wanted, and what was suitable for him.

Martin had a habit of self-asking. In the evening after meeting Ruth, he conceived that his childhood and youth had been troubled by a vague unrest, and he had never known what he wanted. It was Ruth that made him realize that it was beauty, intellect, and love that he must have. That was a clear and definite hope for him then.

Martin's awareness of writing plays an important part in his self-pursuit. He compared himself to a dog sleeping under the sun, for he saw noble and beautiful visions, but he could not express them to Ruth. So he decided to stand up with open eyes, and he would struggle and toil and learn until he could share his versioned wealth with Ruth. The way to realize it was writing. So he started his writing career for this simple and pure reason.

In the process of his self-pursuit in writing, there was an inevitable doubt about himself. He asked himself when he gazed at the looking-glass curiously: "Who are you, Martin Eden? What are you? Where do you belong? Are you going to make good?[1] But the beauty of famous works attracted him, the desire to create occupied him, and the love for Ruth encouraged him. So he sustained in that writing field which he loved, and gradually became mature in his mind toward himself, and had confidence in himself. In a conversation with Ruth, he expressed that writing was the most vital thing in him, and had he been a mere clod, he would not have desired to write. Writing as a media had enriched Martin Eden, and helped him to found his way of career, to form his view on life, and even toward the world. The most important was that it provided a clear mind for him to recognize himself. And that was enough for a person's pursuit of himself.

\section{MARTIN'S SUCCESS AND DisINTEGRATION}

\section{A. Success and Disintegration}

In the latter small part of the novel Martin's success in his career started. One of his works was accepted by a publishing house, then one after another. Most of his works changed their past destiny, and were published by magazines or newspapers or companies. People's attitude toward him changed suddenly. The Judge, the bank manager, and all people of the upper class invited him. And Ruth came back to his arms. This was the success on the "surface." At the same time when all the people crowded around him, Martin Eden's concept of value collapsed. The difference of people's attitude toward him expressed their deep hypocrisy clearly. And indeed he hated it. It seemed for him that the world was not the one he once lived in. The words "WORK PERFORMED" occupied his mind. He just couldn't understand the world, for it was contradicted with his concept of value. At that moment, he lost his purpose, for there was no need for love, and no impulse to write. In a word, he was empty inside. It was a time of disintegration.

That kind of disintegration was expressed vaguely from his self-denying. Different from the long process of his unceasing self-pursuit, after his success, when Ruth came back to him, he told her that he was sick, and there was something wrong with him, not in his body but in his mind, his soul. It seemed that he had lost all values. He cared for nothing. So life had no meaning for Martin then, and all of his pursuits just were in disintegration then. If Martin's muttering aloud the poem "I have had my singing minute. I have done. Put by the lute" showed his potential tiredness toward love, toward knowledge, and toward the world, the line "That dead man rise up never" perfectly reflected his mood at that moment when he read Swinburne's poem in the ship. So he went up and jumped into the sea, totally showed his despair of the disintegration of his concept of value.

\section{B. Hypocrisy of the Society}

Jack London depicts the world as cold, godless, indifferent and hostile to human desire through the fate of Martin Eden. He has succeeded in exposing the bourgeoisies nature of hypocrisy and being interested only in material gain through full expression by contrasting two completely different attitudes which two typical representatives of bourgeoisie treat Martin Eden's failure and success with.

The first category is the so-called wealthy class people, such as lawyers, bankers, the Morses and Judge Bount etc. Though these rich people lived comfortably, dressed well, they were extremely selfish and money-oriented in their dark souls. By contrast, Martin Eden who had written many valuable literary works, was talented, intelligent and scholarly, but he had no opportunity to publish them when he was nobody, and the Morse couple looked down on him and they thought "he had no place in the neither position nor salary. He is impractical."[1] But to arouse her daughter's interest in mankind in general, they began to let their daughter contact Martin because "she has been so singularly backward where men are concerned."'[1] And they didn't think their daughter, Ruth, would fall in love with Martin. They held the view that Ruth only did a safe experiment by making use of this uncouth sailor who considered love the finest thing in the world. Once they felt "the experiment has succeeded. She is awakened at last."[1] Mr. Morse spoke briskly in a business tone "then we'll have to get rid of him."[1] When they found that plan had been broken and that Ruth could not help loving Martin and had become engaged to Martin, the Morse couple tried many ways to take them apart.

Later, Martin finally had succeeded in writing. "Money poured in on him, fame poured in on him; he flashed, comet-like, through the world of literature."[1]. At this time, those bourgeoise politicians, celebrities strived to be the 
first and feared to lag behind to invite him to dinner. Even Judge Blount invited him to dinner, although Martin had insulted him and treated him abominably. What made Martin most surprised was Mr. Morse, who "had forbidden him going to the house and broken the engagement"[1] and who found an excuse to meet him in the hotel Metropole. In fact, Mr. Morse had gone there for the direct purpose of inviting him to dinner. In the face of the inconstancy of human relationships, Martin was more puzzled, and he couldn't help assailing, "When he wanted dinners, no one gave them to him, but when he could buy a hundred thousand dinners and was losing his appetite, dinners were thrust upon him right and left. But why? There was no justice in it; no merit on his part. He was not different, so were his works which were the original ones. Mr. and Mrs. Morse had condemned him for an idler and a shirk, and Ruth had urged that he take a clerk's position in an office. Furthermore, they had been aware of his work performed. Manuscript after manuscript of his had been turned over to them by Ruth. They had read them. It was the same work that had put his name in all the papers, and it was his name being in all the papers that led them to invite him."'[1] His query touched the filthy soul of bourgeoise and exposed their true face of time-serving. He pointed out further: "the Morses had not cared to have him for himself or for his work. Therefore they could not want him now for himself or for his work, but for the fame that was his, that was the way bourgeoise society valued a man." [1] And it revealed the hypocrisy of bourgeoisie.

Ruth was the Morse couple's daughter. "She was a pale, ethereal creature, with wide, spiritual blue eyes and a wealth of golden hair." [1] Her purity and beauty gave such a deep impression on Martin that he likened her to a pale gold flower upon a slender stem. "She was a spirit, a divinity, a goddess; such sublimated beauty was not of the earth." [1]Actually, Ruth loved Martin based on following reasons. The first one was due to the mysterious and novel psychology. She found that Martin was quite different from those macaroni she had met. Martin was full of youthful spirit and perseverance. Moreover, he was honest and intelligent. In contrast with Martin's true love, her love to Martin was conditional. Martin must meet the demand of the bourgeois standard of valuation. She once said to Martin "her ideal of the successful man was largely in her father's image, with a few unmistakable lines and touches of color from the image of Mr.Butler" [1]It meant either Martin had a profession, social status and money or he realized the dream from a nobody to a wealthy man like Bulter. Although Martin thought there was nothing alluring in the picture she drew, he was determined to realize his great ambition because of love. However, she could neither understand Martin's outstanding talents nor appreciate his great aspiration of becoming a famous writer at all, which contributed to a lack of thought exchange and soul mixture. Based on her narrow mind, she reached such a conclusion that she deserted him without hesitation when the people around her began to attack him, saying Martin was the most notorious leader of the Oakland socialists. She held the view that Martin had brought her shame and destroyed her fame and her family. What she had done proved that her prejudice of being snobbish and superficial overweighed her love to Martin.

When fortune was smiling on him and his works were published, Ruth came to Martin's room to resume the engagement. She told him "You know I love you that I am here because I love you." [1] Martin thought "yet I am not a bit more eligible now than I was when she broke our engagement." [1], so he said "When I was just as I am now, as a man, as an artist, the same Martin Eden? That's the question I've been propounding to myself for many days-not concerning you merely, but concerning everybody. You see I have not changed, though my sudden apparent appreciation in value compels me constantly to reassure myself on that point. I've got the same flesh on my bones, the same ten fingers and toes. I am the same. I have not developed any new strength nor virtue. My brain is the same old brain. I haven't made even one new generalization of literature or philosophy. I am personally of the same value that when I was nobody wanted me. And what is puzzling me is why they want me now. Surely they don't want me for myself, for myself is the same old self they did not want. Then they must want me for something else, for something that is outside of me, for something that is not I! Shall I tell you what that something is? It is for the recognition I have received. That recognition is not I. It resides in the minds of others. Then again for the money I have earned and am earning. But that money is not I. It resides in the banks and in the pockets of Tom, Dick, and Harry. And is it for that, for the recognition and the money, that you now want me?" [1] At this moment, Martin had seen through Ruth who was narrow-minded and selfish. As a result, when Ruth begged his pardon and wanted to regain Martin's love, Martin gave an ironic remark, "I'm afraid I am a shrewd merchant, peering into the scales, trying to weigh your love, and find out what manner of thing it is." [1]

Ruth's attitude toward Martin changed greatly because of his fame and money. Her love was based on wealth and social position instead of Martin's talent and hard work. She loved money more than Martin. When Martin became rich, she wanted him without considering her class, her parent and friends, even her own dignity. This indicates that Ruth was very selfish. Martin realized that Ruth's strength of love for him arose from his publication and public notice, thus exposed the false love.

The second category is the selfish and vulgar businessmen, such as Martin's brother-in-law, Bernard Higginbotham and Herman von Schmidt. Before his success, Martin had to live with sister and brother-in-law because of poverty. Higginbotham was a snobbish, mean and tricky businessman. He looked down upon Martin, looking at him with a weasel-like and cruel eye that showed irony and imperiousness. It is a sharp contrast when he made a sale in the store, the same eyes were smug oily and flattering. Therefore, "Martin Eden never looked at him without experiencing a sense of repulsion. What his sister had seen in the man was beyond him. The other affected him as so much vermin, and always aroused in him an impulse to crush him under his foot." [1] Higginbotham treated Martin cold and sharp, even with disgust. When the name of Martin was mentioned, he always snorted. He often examined whether Martin had paid 
the board. If Martin read in bed, he would charge him half a dollar for gas. Furthermore, he constantly made trouble for Martin and found excuses to drive him away. As to Martin's writing, he simply sneerd. The worst was that he wrote an anonymous and slanderous letter about Martin, with assertions that the "so-called Martin Eden" was no writer at all, that in fact he was stealing stories from old-magazines, typing them, and sending them out as his own. He tried to destroy Martin's fame, and asked editors not to publish Martin's manuscripts. Because of propagandizing for socialism, Martin was surrounded by bourgeoise presses with violent speeches. "Higginbotham was furious with him for having dragged the family into public disgrace, and that he had forbidden him the house."[1]When Martin suffered from starvation, he didn't give him a hand at all. But when Martin succeeded in writing, he fawned on him and invited him to have a rich dinner. During the dinner, Higginbotham opened up his heart to Martin, showing his keenness and enormous planning with which he has made the store. It is the fact that he flattered Martin in order to borrow money from him for the only purpose of realizing his ambitious plan.

Herman von Schmidt, Martin's brother-in-law, was a businessman who set up for himself a bicycle-repair shop. He was as selfish and vulgar as Higginbotham. When Martin was poor and not famous, he looked down upon him. He even said "it was indecent, obscene" [1] when Martin wrote an airy and delicate verse for Marian, Martin's sister. In addition, he asserted that he didn't want anything to do with him in any shape, manner or form. However, when Martin had become a famous writer, a magazine published this poem on a striking page with decorations. Herman von Schmidt forgot that he had called the verses obscene .He announced that his wife had inspired Martin to write the poem, and the news reached the ears of a reporter, the result was a full page in a Sunday supplement, filled with photographs and idealized drawings of Marian, with many intimate details of Martin Eden and his family. It caused a stir in the neighborhood, making Herman and his repair shop famous. Many people came to his shop for repairing, so he made a fortune. He told Marian "Better than advertising and it costs nothing." [1] He invited Martin to dinner because he found that his brother-in-law was a goodly asset to him. Through these two vivid figures of Higginbotham and Herman, this novel narrates that the bourgeoise only search for money. The word of kinship means nothing to bourgeoisie. The relationship between people is based on money.

\section{CONCLUSION}

The novel's main part deals with the process of Martin Eden's hard pursuit, including his strong desire for love, beauty and knowledge, and a clear idea of himself. In this process the author describes in vivid words the hard condition of the hero's life and his unusual diligence, thus portrays an image of a young man with strong power and enthusiasm inside to continue his pursuit and realize his dream. At the same time, the exposure of hypocrisy of the upper class forms a clear contrast with the hero. The tragic ending of Martin Eden strongly criticizes the society's concept of value. The background of the empty upper class and the society reflects Martin's truly pursuit of his dream. And his pursuing spirit seems especially precious in that kind of world.

\section{REFERENCES}

[1] Chang Yaoxin. (1990). A Survey of American Literature.Nanjing: Nanjing University Press.

[2] Eahe Labor. (1974). Jack London. New York: Twayne.

[3] Jack London. (1986). Martin Eden. Beijing: Commercial Press.

[4] Li Gongzhao. (2000). An Introduction to $20^{\text {th }}$ Century American Literature.Xi'an : Xi'an Jiaotong University Press.

[5] Wang Yaohui. (2000). Literary Text Interpretation. Wu Han: Huazhong Normal University Press.

[6] Xu xixiang. (2002). The Reason of Jack London's Early Novels.Journal of Nantong Normal University, 2, 79-80.

[7] Zhu Gang. (2002). Literary History of the United States.Shanghai: Shanghai Foreign Language Education Press.

[8] Zhong Jiya. (2001). An Inescapable Circle. Foreign Literature, 1, 76-81.

[9] Zhang Yaqin. (2000). Jack London and His Works. Shaanxi Radio and TV University Journal, 9, 101-103.

Rong Hou was born in Yicheng, China in 1983. She received her Master's degree in English language and literature from Xi'an International Studies University, China in 2009.

She is currently an English teacher in the School of Foreign Languages, Shan'xi Normal University, Linfen, China. Her research interests mainly focus on American literature. 